\title{
PEMANFAATAN DAN OPTIMALISASI LAHAN KERING UNTUK PENGEMBANGAN BUDIDAYA TANAMAN PALAWIJA DI DESA PUDAY KECAMATAN WONGEDUKU KABUPATEN KONAWE PROVINSI SULAWESI TENGGARA
}

\author{
Helviani ${ }^{1}$, Aan Wilhan Juliatmaja ${ }^{2}$, Doddy Ismunandar Bahari ${ }^{3}$, Masitah ${ }^{4}$, \\ Husnaeni 5 \\ 1,2,3,4,5Universitas Sembilanbelas November Kolaka, Kolaka, Indonesia \\ *Penulis Koresponsensi, email: vhi.helvi@gmail.com
}

Abstract. Land is one of the potential natural resources to be developed optimally to increase local revenue. Based on the availability of water, land is grouped into two major groups, which are wetland and dry land (upland). The use of dry land for agriculture is often ignored by policy makers. Problems in dry land management vary in each region, both technical and socio-economic aspects. However, with the right strategy and technology, these problems can be overcome. Efforts to manage dry land to increase food production face problems, including steep slopes, low soil fertility, and water shortages. These problems need to be overcome by applying the right technology. Dry land management technology is available, including management of soil fertility, soil conservation, land rehabilitation, and efficient management of water resources. The problem is the weak dissemination of innovative technology to farmers and the slow adoption of this technology. Utilization of dry land to increase food production requires appropriate planning and strategies.

Keywords: Optimization, Dryland, Palawija

\begin{abstract}
Abstrak. Lahan merupakan salah satu sumberdaya alam yang potensial untuk dikembangkan seoptimal mungkin untuk meningkatkan pendapatan asli daerah. Berdasarkan ketersediaan airnya, maka lahan dikelompokkan ke dalam dua kelompok besar, yaitu lahan basah (wetland) dan lahan kering (upland). Pemanfaatan lahan kering untuk pertanian sering diabaikan oleh para pengambil kebijakan. Permasalahan dalam pengelolaan lahan kering bervariasi pada setiap wilayah, baik aspek teknis maupun sosial ekonomis. Namun, dengan strategi dan teknologi yang tepat, berbagai masalah tersebut dapat diatasi. Upaya pengelolaan lahan kering untuk meningkatkan produksi bahan pangan menghadapi permasalahan, antara lain lahan berlereng terjal, kesuburan tanah rendah, dan kekurangan air. Berbagai masalah tersebut perlu diatasi dengan menerapkan teknologi yang tepat. Teknologi pengelolaan lahan kering telah tersedia, mencakup pengelolaan kesuburan tanah, konservasi tanah, rehabilitasi lahan, dan pengelolaan sumberdaya air secara efisien. Yang menjadi masalah adalah lemahnya diseminasi teknologi inovatif kepada para petani dan lambatnya adopsi teknologi tersebut. Pemanfaatan lahan kering untuk meningkatkan produksi bahan pangan memerlukan perencanaan dan strategi yang tepat.
\end{abstract}

Kata Kunci: Optimalisasi, Lahan Kering, Palawija

How to Cite: Helviani, H., Juliatmaja, A. W. ., Bahari, D. I. . ., Masitah , M. ., \& Husnaeni , H. . (2021). PEMANFAATAN DAN OPTIMALISASI LAHAN KERING UNTUK PENGEMBANGAN BUDIDAYA TANAMAN PALAWIJA DI DESA PUDAY KECAMATAN WONGEDUKU KABUPATEN KONAWE PROVINSI SULAWESI TENGGARA . Mitra Mahajana: Jurnal Pengabdian Masyarakat,2(1), 49-55. https://doi.org/10.37478/mahajana.v2i1.806

\section{PENDAHULUAN}

Esensi otonomi daerah salah satunya adalah untuk melakukan optimalisasi potensi sumberdaya yang dimiliki sebagai modal dasar pembangunan di daerahnya. Lahan merupakan salah satu sumberdaya alam yang potensial untuk dikembangkan seoptimal mungkin untuk meningkatkan pendapatan asli daerah (PAD). Lahan menjadi sumberdaya yang penting peranannya karena hampir seluruh sektor pembangunan fisik membutuhkan lahan, terutama untuk sektor pertanian. Berdasarkan ketersediaan airnya, maka lahan dikelompokkan ke dalam dua kelompok besar, yaitu lahan basah (wetland) dan lahan kering (upland). Namun, beberapa penulis ada yang menggunakan istilah dryland sebagai definisi atas lahan kering yang sama sekali tidak mendapat pengaruh air hujan lagi (Notohadiprawiro, 1989). Pengelolaan lahan kering berbeda dengan lahan basah karena perbedaan faktor pembatas penggunaannya. 
Pemanfaatan lahan kering untuk pertanian sering diabaikan oleh para pengambil kebijakan, yang lebih tertarik pada peningkatan produksi beras pada lahan sawah. Lahan kering yang potensial dapat menghasilkan bahan pangan yang cukup dan bervariasi. Bahan pangan bukan hanya beras, tetapi juga jagung, sorgum, kedelai, kacang hijau, ubi kayu, ubi jalar, dan sebagainya, yang kesemuanya dapat dibudidayakan di lahan kering. Lahan kering merupakan salah satu agroekosistem yang mempunyai potensi besar untuk usaha pertanian, baik tanaman pangan, hortikultura (sayuran dan buah-buahan) maupun tanaman tahunan dan peternakan. Berdasarkan Atlas Arahan Tata Ruang Pertanian Indonesia skala 1:1.000.000 (Pusat Penelitian dan Pengembangan Tanah dan Agroklimat, 2001), Indonesia memiliki daratan sekitar 188,20 juta ha, terdiri atas 148 juta ha lahan kering (78\%) dan 40,20 juta ha lahan basah (22\%).

Permasalahan dalam pengelolaan lahan kering bervariasi pada setiap wilayah, baik aspek teknis maupun sosial ekonomis. Namun, dengan strategi dan teknologi yang tepat, berbagai masalah tersebut dapat diatasi. Dari segi luas, potensi lahan kering tergolong tinggi, namun terdapat permasalahan biofisik dan sosial ekonomi yang harus diatasi untuk meningkatkan produktivitasnya secara berkelanjutan. Beberapa tindakan untuk menanggulangi faktor pembatas biofisik lahan meliputi pengelolaan kesuburan tanah, konservasi dan rehabilitasi tanah, serta pengelolaan sumber daya air secara efisien. Pengelolaan kesuburan tanah tidak terbatas pada peningkatan kesuburan kimiawi, tetapi juga kesuburan fisik dan biologi tanah. Hal ini berarti bahwa pengelolaan kesuburan tanah tidak cukup dilakukan hanya dengan memberikan pupuk saja, tetapi juga perlu disertai dengan pemeliharaan sifat fisik tanah sehingga tersedia lingkungan yang baik untuk pertumbuhan tanaman, kehidupan organisme tanah, dan untuk mendukung berbagai proses penting di dalam tanah. Salah satu teknologi pengelolaan kesuburan tanah yang penting adalah pemupukan berimbang, yang mampu memantapkan produktivitas tanah pada level yang tinggi.

Kendala produksi di lahan kering adalah kondisi fisik lahan (kedalaman tanah relatif dangkal, lereng curang, kekeringan), teknologi / penerapan teknik konservasi lemah dan sosial ekonomi (ketiadaan modal untuk menerapkan teknologi anjuran). Akibat dari kendala fisik, teknologi dan sosial ekonomi tersebut adalah produktivitas lahan terus menurun sehingga jumlah penduduk miskin terus bertambah (Hidayat dan Mulyani 2002; Suriadikarta, et. al. 2002). Oleh karena itu pengelolaan lahan kering yang tepat yang mengarah pada peningkatan produksi yang berkesinambungan mutlak diperlukan. Salah satu upaya yang dapat dilakukan untuk memecahkan masalah yang dihadapi petani di lahan kering adalah mengembangkan teknologi usahatani yang sesuai dengan kondisi setempat. Teknologi pengelolaan lahan kering yang umum dilakukan meliputi: konservasi air dan pemanfaatan bahan organik, dan akan semakin berarti apabila diintegrasikan dengan usahatani ternak, karena dalam implementasinya konservasi lahan dan air akan terjamin keberlanjutannya jika diintegrasikan dengan ternak (Subiharta, dkk., 2007).

Hasil penelitian Lasmini, dkk., (2017) menyatakan bahwa kendala produksi di lahan kering adalah kondisi fisik lahan, teknologi / dan sosial ekonomi. Oleh karena itu pengelolaan lahan kering yang tepat yang mengarah pada peningkatan produksi yang berkesinambungan mutlak diperlukan. Salah satu upaya yang dapat dilakukan adalah mengembangkan teknologi usahatani yang sesuai dengan kondisi setempat. Teknologi pengelolaan lahan kering yang umum dilakukan meliputi : konservasi air dan pemanfaatan bahan organik, dan akan semakin berarti apabila diintegrasikan dengan usahatani ternak, karena dalam implementasinya konservasi lahan dan air akan terjamin keberlanjutannya jika diintegrasikan dengan ternak. Dengan merekayasa model pengelolaan usahatani lahan kering sesuai dengan kearifan lokal masyarakat diharapkan dapat menjadi model pengembangan lahan kering berkelanjutan yang berwawasan agribisnis.

Hasil penelitian Santoso, et al., (1995) menunjukkan pentingnya pemupukan berimbang dan pemantauan status hara tanah secara berkala. Penggunaan pupuk anorganik yang tidak tepat, misalnya takaran tidak seimbang, serta waktu pemberian dan penempatan pupuk yang salah, dapat mengakibatkan kehilangan unsur hara sehingga respons tanaman menurun 
(Santoso dan Sofyan, 2005). Hara yang tidak termanfaatkan tanaman juga dapat berubah menjadi bahan pencemar. Praktek pemakaian pupuk oleh petani pada lahan-lahan mineral masam, meskipun pada saat ini masih dilakukan dengan takaran rendah, dalam jangka panjang dapat menimbulkan ketidakseimbangan kandungan hara tanah sehingga menurunkan produktivitas tanaman.

\section{METODE PELAKSANAAN}

Penyelesaian Masalah dalam memanfaatkan lahan kering di daerah pengabdian merupakan suatu kegiatan yang dilakukan dalam beberapa langkah yaitu :

1) Rapat dengar pendapat antara pihak petani, pihak pemerintah setempat, serta pihak pelaksana pengabdian. Pihak petani diwakili oleh Kelompok Dusun II Puday, pihak pemerintah setempat diwakili oleh Kepala Desa Puday dan perangkat desa terkait. Kegiatan rapat dengar pendapat ini dilakukan untuk mengetahui persoalan terkait pengelolaan lahan, penilaian, dan penetapan lokasi.

2) Perencanaan Kegiatan dilakukan dengan penjadwalan, metode, penetuan pihak yang terlibat, bahan dan peralatan yang dibutuhkan, dan pembiayaan.

3) Kegiatan pengendalian pengabdian berupa fasilitasi, supervisi, dan penilailan.

Adapun pelaksanaan teknis dilapangan dilakukan dengan :

1) Persiapan lahan dilokasi pengabdian dengan menggunakan sebidang tanah masyarakat Kelompok Tani Dusun II Puday.

2) Pembuatan bedengan pada lahan tersebut untuk mengurangi run-off pada permukaan lahan.

3) Penggunaan bahan organik hingga 100 persen untuk bahan pupuk yang berasal dari Kotoran Ayam dan sisa tanaman.

4) Persiapan bibit tanaman semusim.

5) Persiapan tempat penampungan mulsa dan penjadwalan pengumpulan mulsa setiap harinya yang berasal dari tanaman sekitar.

6) Pembuatan penampungan air

Kegiatan tersebut merupakan kegiatan yang dilakukan oleh seluruh stakeholder terkait yakni petani dan penyelenggara pengabdian. Kegiatan tersebut merupakan bentuk penerapan konsep pertanian organik sebagai salah satu cara peningkatan nilai hasil produksi pada lahan kering. Peningkatan nilai jual akan memberikan kompensasi pada pengurangan hasil produksi pertanian pada lahan kering.

\section{HASIL DAN PEMBAHASAN}

Beberapa tindakan untuk menanggulangi faktor pembatas biofisik lahan meliputi pengelolaan kesuburan tanah, konservasi dan rehabilitasi tanah, serta pengelolaan sumber daya air secara efisien. Pengelolaan kesuburan tanah terdiri dari peningkatan kesuburan kimiawi, fisik dan biologi tanah. Salah satu teknologi pengelolaan kesuburan tanah yang penting adalah pemupukan berimbang, yang mampu memantapkan produktivitas tanah pada level yang tinggi. Pemupukan berimbang dan pemantauan status hara tanah secara berkala penting untuk dilakukan agar tingkat kesuburan tanah dapat diketahui.

Penggunaan pupuk anorganik yang tidak tepat, misalnya takaran tidak seimbang, serta waktu pemberian dan penempatan pupuk yang salah, dapat mengakibatkan kehilangan unsur hara sehingga respons tanaman menurun (Santoso dan Sofyan, 2005). Hara yang tidak termanfaatkan tanaman juga dapat berubah menjadi bahan pencemar. Penerapan teknologi pemupukan organik juga sangat penting dalam pengelolaan kesuburan tanah. Pupuk 
organik dapat bersumber dari sisa panen, pupuk kandang, kompos atau sumber bahan organik lainnya. Selain menyumbang hara yang tidak terdapat dalam pupuk anorganik, seperti unsur hara mikro, pupuk organik juga penting untuk memperbaiki sifat fisik dan biologi tanah. Lahan kering akan mampu menyediakan air dan hara yang cukup bagi tanaman bila struktur tanahnya baik sehingga mendukung peningkatan efisiensi pemupukan.

Erosi merupakan salah satu penyebab menurunnya produktivitas lahan kering, terutama yang dimanfaatkan untuk usaha tani tanaman semusim seperti tanaman pangan (Abdurachman dan Sutono 2005). Hasil penelitian menunjukkan budi daya tanaman pangan semusim tanpa disertai konservasi tanah menyebabkan erosi berkisar antara 46-351 t/ha/tahun (Sukmana, 1994;1995). Erosi bukan hanya mengangkut material tanah, tetapi juga hara dan bahan organik, baik yang terkandung di dalam tanah maupun yang berupa input pertanian. Penerapan teknik konservasi merupakan salah satu prasyarat keberlanjutan usahatani lahan kering.

Teras bangku merupakan teknik konservasi yang telah dikembangkan secara luas sejak tahun 1975 melalui inpres penghijauan (Siswomartono, et al. 1990). Teras bangku cukup disukai petani, dan juga efektif mencegah erosi dan aliran permukaan (Abdurachman dan Sutono 2005). Beberapa teknik konservasi alternatif, seperti teras gulud untuk tanah yang dangkal $(<40 \mathrm{~cm})$, rorak atau teknik konservasi vegetatif seperti alley cropping dan strip rumput. Selain murah, teknik konservasi vegetatif memiliki keunggulan lain, yaitu dapat berfungsi sebagai sumber pakan dan pupuk hijau atau bahan mulsa. Dalam prakteknya, penerapan teknik konservasi mekanik sering dikombinasikan dengan teknik vegetatif, karena efektif dalam mengendalikan erosi (Dariah, et al. 2004) dan lebih cepat diadopsi petani.

Pengaturan pola tanam dengan mengusahakan permukaan lahan selalu tertutup oleh vegetasi dan/atau sisa-sisa tanaman atau serasah, juga berperan penting dalam konservasi tanah. Pengaturan proporsi tanaman semusim dan tahunan pada lahan kering juga penting; makin curam lereng sebaiknya makin tinggi proporsi tanaman tahunan. Pengaturan jalur penanaman atau bedengan yang searah kontur juga berkontribusi dalam mencegah erosi. Pengolahan tanah secara intensif merupakan penyebab penurunan produktivitas lahan kering.

Hasil penelitian menunjukkan bahwa pengolahan tanah yang berlebihan dapat merusak struktur tanah (Larson dan Osborne, 1982; Suwardjo, et al. 1989) dan menyebabkan kekahatan bahan organik tanah (Rachman, et al. 2004). Olah tanah konservasi (OTK) merupakan alternatif penyiapan lahan yang dapat mempertahankan produktivitas lahan tetap tinggi (Brown, et al. 1991). Ciri OTK adalah berkurangnya pembongkaran atau pembalikan tanah, mengintensifkan penggunaan sisa tanaman atau bahan lainnya sebagai mulsa, kadang-kadang (namun tidak dianjurkan) disertai penggunaan herbisida untuk menekan pertumbuhan gulma atau tanaman pengganggu lainnya. Rehabilitasi lahan-lahan terdegradasi dapat mendukung optimalisasi lahan kering, antara lain dengan menanam legume penutup tanah atau tanaman penghasil bahan organik lainnya, khususnya yang bersifat in situ seperti alley cropping dan strip cropping. Penggunaan bahan pembenah tanah baik organik maupun mineral juga dapat merehabilitasi lahan terdegradasi.

Kelangkaan air sering kali menjadi pembatas utama dalam pengelolaan lahan kering. Oleh karena itu, inovasi teknologi pengelolaan air dan iklim sangat diperlukan, meliputi teknik $\mathrm{p}$ anen hujan (water harvesting), irigasi suplemen, prediksi iklim, serta penentuan masa tanam dan pola tanam. Pemanenan air dapat dilakukan dengan menampung air hujan atau aliran permukaan pada tempat penampungan sementara atau permanen, untuk digunakan mengairi tanaman (Subagyono et al. 2004). Oleh karena itu, pemanenan air selain berfungsi menyediakan air irigasi pada musim kemarau, juga dapat mengurangi risiko banjir pada musim hujan. Teknologi ini bermanfaat untuk lahan yang tidak mempunyai jaringan irigasi atau sumber air bawah permukaan (ground water). 


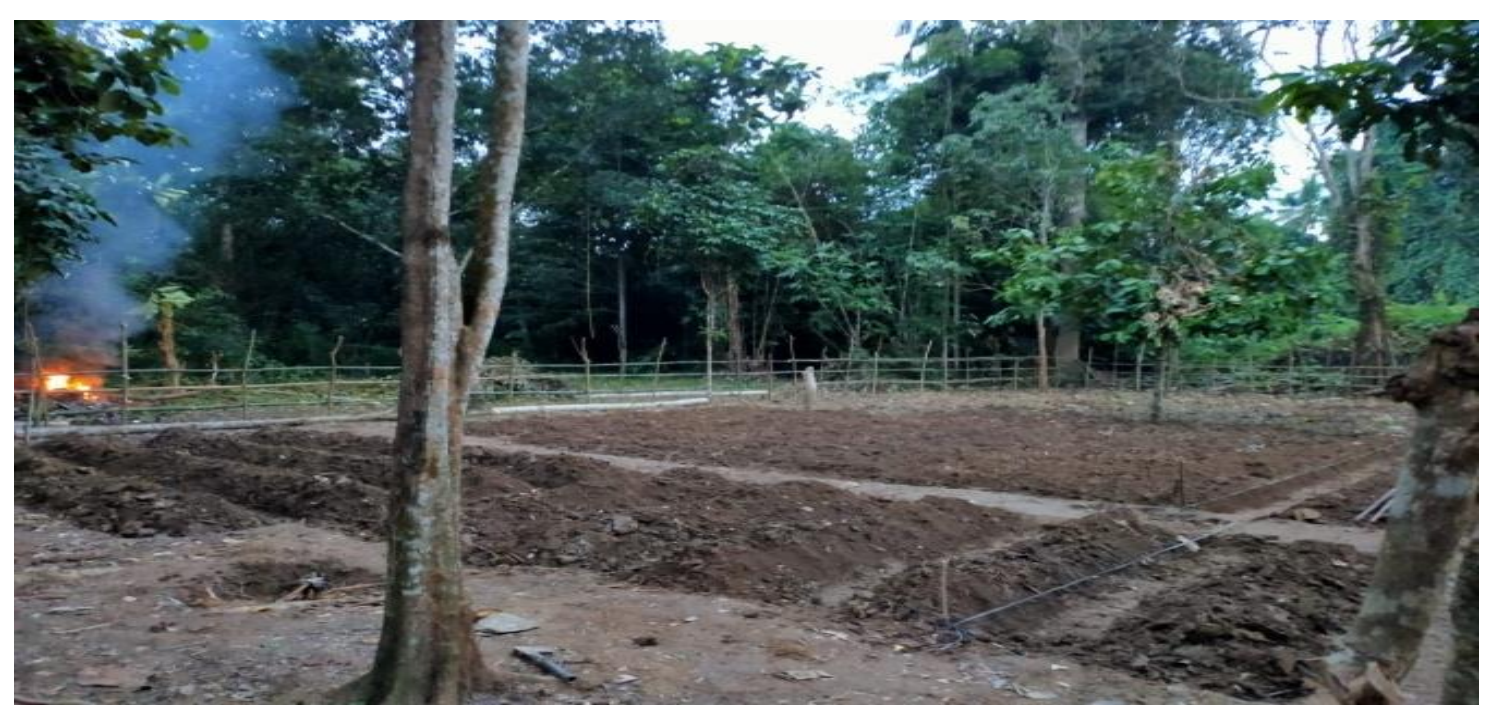

Gambar 1. Persiapan Lahan Kering di Daerah Pengabdian
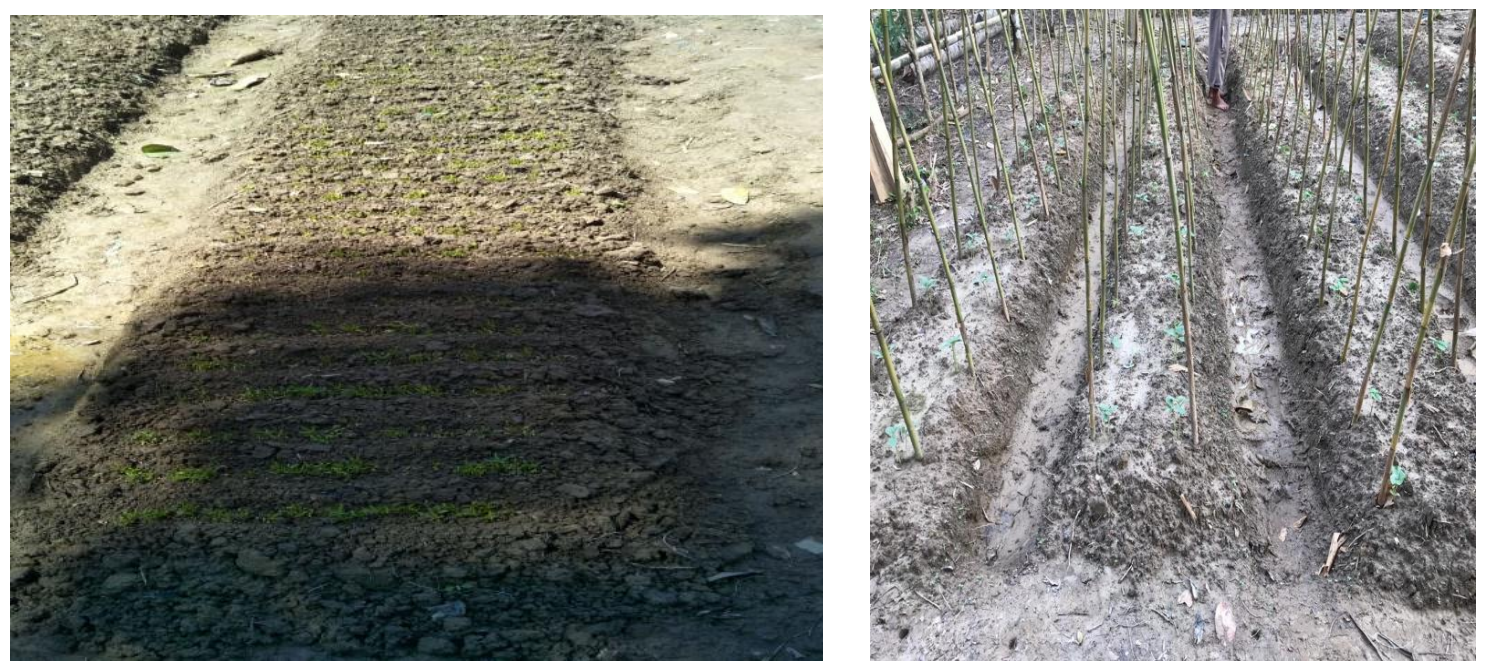

Gambar 2. Lahan Kering di Daerah Pengabdian
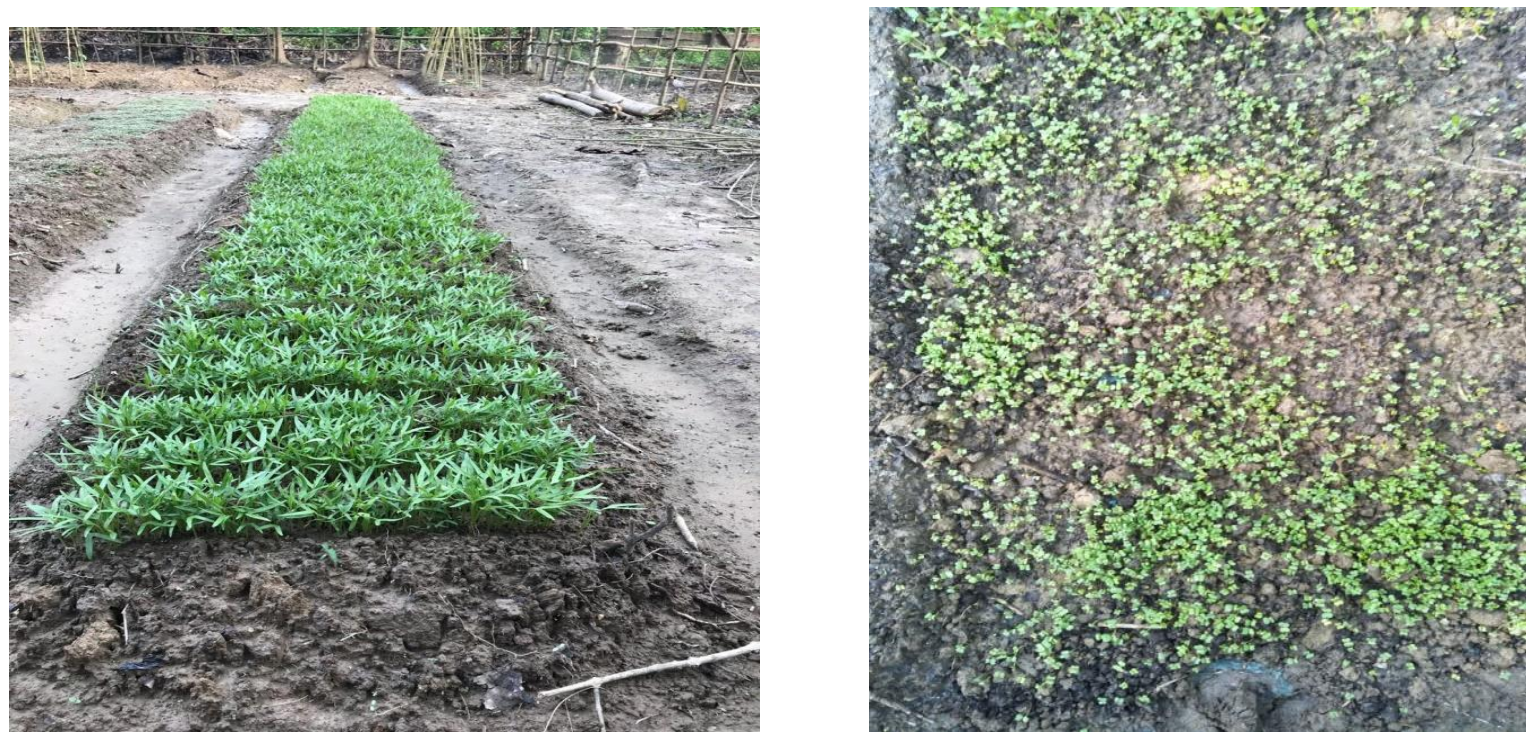

Gambar 3. Pengolahan Lahan Kering di Daerah Pengabdian 


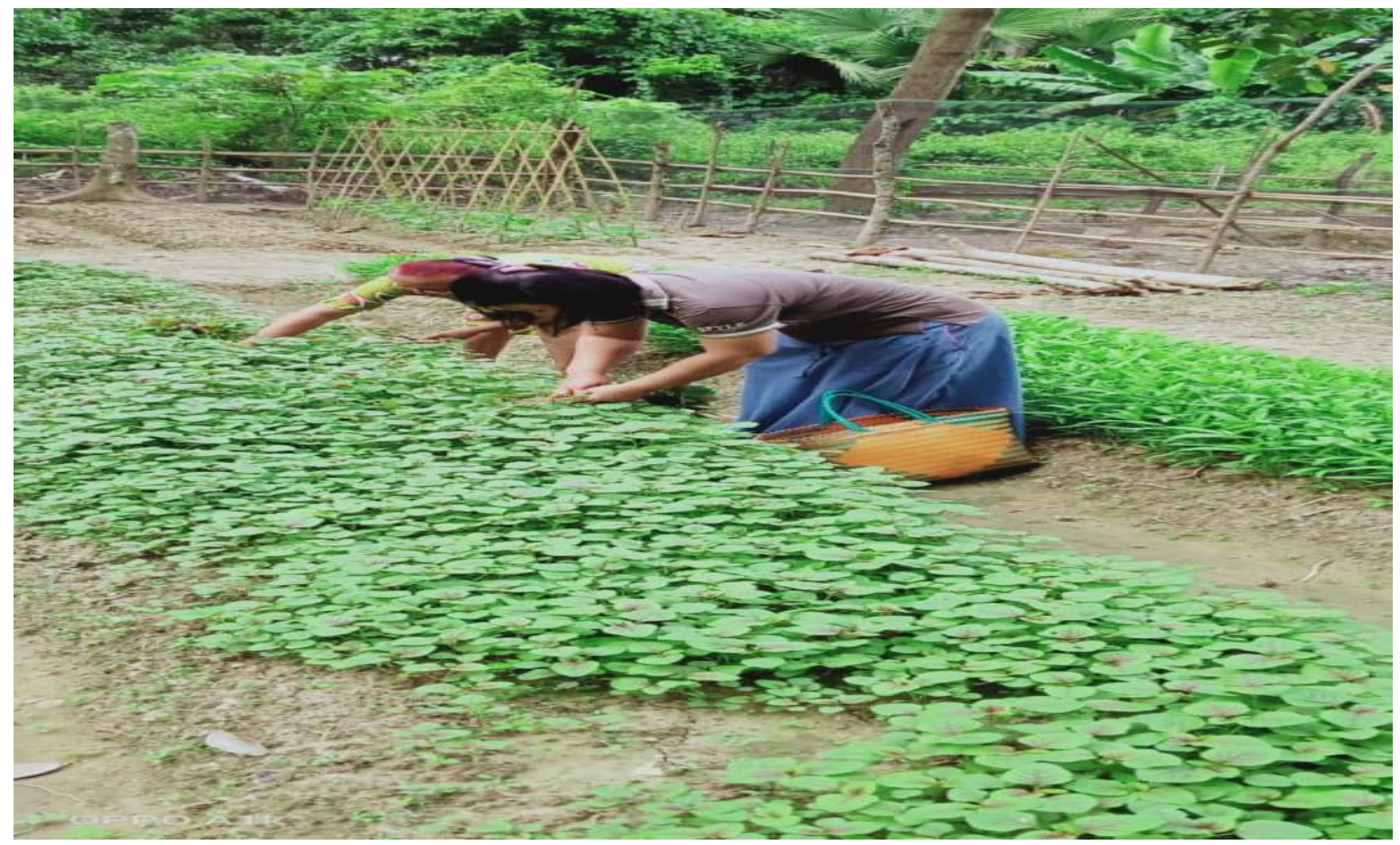

Gambar 4. Pengolahan Lahan Kering di Daerah Pengabdian

\section{SIMPULAN DAN TINDAK LANJUT}

Untuk mengoptimalkan pemanfaatan lahan kering melalui peningkatan produktivitas lahan pertanian yang sudah ada saat ini, dan perluasan lahan pertanian tanaman pangan dengan memanfaatkan lahan kering terlantar. Upaya pengelolaan lahan kering untuk meningkatkan produksi bahan pangan menghadapi permasalahan, antara lain lahan berlereng terjal, kesuburan tanah rendah, dan kekurangan air. Berbagai masalah tersebut perlu diatasi dengan menerapkan teknologi yang tepat. Teknologi pengelolaan lahan kering telah tersedia, mencakup pengelolaan kesuburan tanah, konservasi tanah, rehabilitasi lahan, dan pengelolaan sumberdaya air secara efisien. Yang menjadi masalah adalah lemahnya diseminasi teknologi inovatif kepada para petani dan lambatnya adopsi teknologi tersebut. Pemanfaatan lahan kering untuk meningkatkan produksi bahan pangan memerlukan perencanaan dan strategi yang tepat.

\section{DAFTAR PUSTAKA}

Abdurachman, A. \& Sutono, S. (2005). Teknologi pengendalian erosi lahan berlereng. Dalam Teknologi Pengelolaan Lahan Kering: Menuju pertanian produktif dan ramah lingkungan. Bogor: Pusat Penelitian dan Pengembangan Tanah dan Agroklimat

Abdurrachman, A., Dariah, D \& Mulyani, A. (2008). Strategi dan teknologi pengelolaan lahan kering mendukung pengadaan pangan nasional. J. Litbang Pertanian, 27(2):43-49. http://203.190.37.42/publikasi/p3272081.pdf

Brown, R.E, Havlin, J.L., Lyons, D.J., Fenster, C.R. \& Peterson G.A. (1991). Longterm tillage and nitrogen effects on wheat production in a wheat fallow rotation. p. 326 In Agronomy Abstracts. Annual Meetings ASA, CSSA, and SSSA, Denver Colorado, Oct 27 - Nov 1, 1991

Dariah, A., Rachman, A. \& Kurnia U. (2004). Erosi dan degradasi lahan kering di Indonesia. Dalam U. Kurnia, A. Rachman, dan A. Dariah (Ed.). Teknologi Konservasi Tanah pada Lahan Kering Berlereng. Bogor: Pusat Penelitian dan Pengembangan Tanah dan Agroklimat 
Hidayat, H \& Mulyani, M. (2002). Lahan Kering untuk pertanian dalam Teknologi Pengelolaan Lahan Kering. Pusat Penelitian Tanah dan Agroklimat. Badan Litbang Pertanian. Jakarta: Departemen Pertanian

Lasmini, S. A., Imam, W., \& Nurhayati. (2017). Optimalisasi Lahan Kering untuk Meningkatkan Pendapatan Masyarakat Berbasis Inovasi Teknologi dan Kearifan Lokal. Fakultas Pertanian Universitas Tadulako

Larson, W. E. \& Osborne, G. J. (1982). Tillage accomplishments and potential. In Predicting Tillage Effects on Soil Physical Properties and Processes. ASA Special Publication No. 44

Notohadiprawiro. T. (1998). Tanah dan Lingkungan. Jakarta: Direktorat Jendral Departemen Pendidikan dan Kebudayaan

Pusat Penelitian dan Pengembangan Tanah dan Agroklimat.(2001). Atlas Arahan Tata Ruang Pertanian Indonesia Skala 1:1.000.000

Rachman, A., Anderson, S.H., Gantzer,C.J. \& Alberts, E.E. (2004). Soil hydraulic properties influenced by stiff-stemmed grass hedge systems. Soil Sci. Soc. Am. J. 68: 1.386-1.393

Santoso, D., Wigena, I. P.G., Eusof, Z \& Xuhui, C. (1995). The Asian land management of sloping lands network: Nutrient balance study on sloping land. p. 103-108. In A. Maglinao and A. Sajjapongse (Eds.). International Workshop on Conservation Farming for Sloping Upland in South East Asia: Challenge, Opportunities, and Prospects. IBSRAM Proc. No. 14. Bangkok, Thailand

Santoso, D. \& Sofyan, A. (2005). Pengelolaan hara tanaman pada lahan kering. Dalam Teknologi Pengelolaan Lahan Kering: Menuju Pertanian Produktif dan Ramah Lingkungan. Bogor: Pusat Penelitian Tanah dan Agroklimat

Siswomartono, D., Gintings, A. N., Sebayong, K. \& Sukmana, S. (1990). Development of Consevation Farming System. Indonesia Country Review. Regional Avtion Learning Programme on The Development of Conservation Farming System. Report of Inaugural Workshop. 23 Feb-1 March 1990. Chiangmai Thailand

Subagyono, K., Marwanto, S., Tafakresnanto, C., Budyastoro, T \& Dariah, A. (2004). Delineation of Erosion Areas in Sumberjaya, West Lampung. In Refinement of Soil Conservation/Agroforestry Measures Coffee Base Farming Systems. Soil Research Institute. ICRAF (ASB Phase 3 Project)

Subiharta,S., Hartoyo, B \& Anwar, H. (2007). Teknologi Sistem Usahatani Integrasi Tanaman Dan Ternak Berbasis Tanaman Pangan Di Lahan Kering. Bogor: Pusat Penelitian Tanah dan Agroklimat

Sukmana, S. (1994). Budi daya lahan kering ditinjau dari konservasi tanah. hlm. 25-39. Dalam Prosiding Penanganan Lahan Kering Marginal melalui Pola Usaha Tani Terpadu. Jambi, 2 Juli 1994. Bogor: Pusat Penelitian Tanah dan Agroklimat

Sukmana, S. (1995). Teknik konservasi tanah dalam penanggulangan degradasi tanah pertanian lahan kering. hlm. 23 -42. Dalam Prosiding Pertemuan Pembahasan dan Komunikasi Hasil Penelitian Tanah dan Agroklimat. Bogor: Pusat Penelitian Tanah dan Agroklimat

Suriadikarta, D.A., Trihatini, D. Setyorini, dan W. Hartatiek. (2002). Teknologi pengelolaan bahan organik tanah dalam Teknologi Pengelolaan Lahan Kering Menuju Pertanian Produktif dan Ramah Lingkungan. Pusat Penelitian dan Pengembangan Tanah dan Agroklimat, Bogor. hlm. 183-238

Suwardjo, H., Abdurachman,A., \& Abujamin, S. (1989). The use of crop residue mulch to minimize tillage frequency. Pembrit. Penel. Tanah dan Pupuk 8: 31-37 